\title{
ANALISIS PENGARUH PERUBAHAN SUHU EVAPORATOR TERHADAP KINERJA KOMPRESOR AC INVERTER
}

\author{
Fahriza Mayrullah $^{1}$ \\ ${ }^{1}$ Politeknik Negeri Banjarmasin \\ mayrullahsosmed@gmail.com
}

\begin{abstract}
Abstrak - Teknologi inverter yang diaplikasikan pada air conditioner menggunakan motor bldc 3 phasa sebagai penggerak kompresor. Motor BLDC 3 phasa dikemudikan oleh IPM (intelligent power module) dan mikrokontroller. Pada saat AC inverter dihidupkan, sesaat mikrokontroller akan membaca input data dari sensor-sensor temperatur, tekanan refrigeran, kemudian mencari posisi rotor untuk melakukan komutasi elektrik. Rentang pengkondisian suhu adalah $16^{\circ} \mathrm{C}-30^{\circ} \mathrm{C}$. Jika target suhu (TS) yang dipilih lebih rendah dari suhu aktual evaporator (SE), maka motor kompresor akan berputar maksimal. Setelah AC on dan SE sudah lebih rendah dari TS maka putaran kecepatan motor kompresor akan pelan. Variasi kecepatan ini menyebabkan energi (E) yang digunakan juga berubah-ubah. Penulis tertarik untuk melakukan penelitian pengaruh perubahan suhu evaporator (PSE) terhadap kinerja kompresor (COP dan EER). Penelitian akan dilakukan selama 2 jam dengan pengambilan data per 15 menit. Tujuan dari penelitian ini yang pertama adalah mengidentifikasikan PSE dan kinerja kompresor (COP dan EER) kemudian yang kedua adalah mengetahui PSE dan pengaruhnya terhadap kinerja kompresor (COP dan EER) selama 2 jam. PSE adalah nilai suhu akhir evaporator dikurangi dengan nilai suhu awal evaporator. COP (coefficient of performance) atau koefisien prestasi adalah salah satu indeks dari kinerja kompresor berdasarkan kerja kompresor. Dimana semakin tinggi nilai COP maka kinerja kompresor semakin baik. EER (Energy Efficiency Ratio) merupakan rasio perbandingan antara energi yang digunakan dengan beban pendingan (cooling load) atau dikenal juga $\mathrm{kW} /$ ton. Semakin tinggi nilai EER maka efisiensi dari kompresor semakin tinggi. Jadi semakin tinggi nilai COP dan EER maka kinerja kompresor semakin baik. Dari hasil pengukuran
\end{abstract}

dan perhitungan didapatkan untuk nilai terendah $\mathrm{PSE}=-7,2$ menghasilkan nilai COP dan EER tertinggi yaitu, $\mathrm{COP}=22,27$ dan $\mathrm{EER}=76,00$. Pada bagian kesimpulan didapatkan analisa bahwa semakin kecil perubahan suhu evaporator (PSE) maka kinerja kompresor AC inverter semakin baik.

\section{kata kunci : Air Conditional, Inverter, Evaporator, Kinerja, Kompresor}

\section{PENDAHULUAN}

Kunci pengembangan terbaru dari teknologi inverter besutan LG sangat bergantung dari kehandalan sirkuit mikro processor yang terletak pada kompresornya. Pemanfaatan sirkuit ini memungkinkan mesin pendingin ruangan berteknologi inverter untuk mengubah jenis arus listrik yang masuk dari arus bolak-balik (alternating current) menjadi arus listrik searah (direct current) sebagai keluarannya. Cara kerja kompresor ini, ketika suhu evaporator (SE) telah mencapai derajat yang sesuai keinginan pengguna, kompresor pada inverter pengembangan terbaru ini masih akan tetap bekerja namun dengan laju putaran yang menyesuaikan dengan naik-turunnya SE. Artinya, cepat lambatnya kompresor bekerja akan sesuai dengan informasi yang diterima sensor untuk memantau bilamana terjadi perubahan suhu pada evaporator. Pada penelitian ini akan menganalisa pengaruh perubahan suhu evaporator (PSE) terhadap kinerja kompresor pada AC inverter. PSE didapatkan dengan cara mengurangi nilai suhu akhir evaporator dengan suhu awal evaporator. Sedangkan kinerja kompresor berdasarkan nilai dari COP dan EER 


\section{METODE PENELITIAN}

\section{Tahapan Penelitian}

1. Lokasi : objek penelitian berada di ruang staf upt pp poliban di Jalan H.Hasan Basry Komplek Unlam Banjarmasin.

2. Alat : remote control untuk pengaturan suhu (TS), Digital infrared thermal gun untuk pengukuran suhu evaporator (SE), Stop watch digital untuk pengukuran waktu (t), Multimeter dan ac electric detector untuk pengukuran tegangan, arus, daya dan energi (V, I, PF, P dan E).

3. Bahan : Air Conditioner LG Smart Inverter1 pk Model T10EMV.

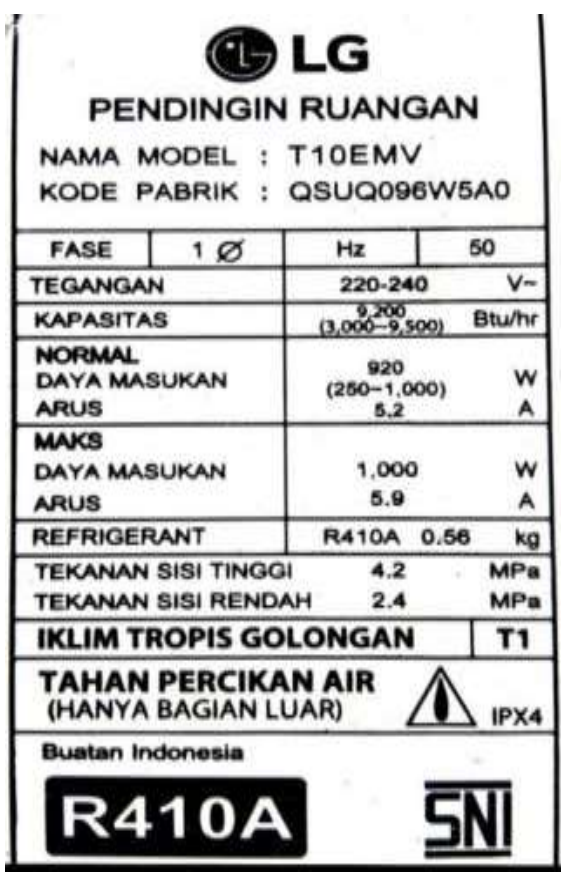

Gambar 1. Spesifikasi AC inverter LG

T10EMV (PT. LG Electronics Indonesia, 2016)

\section{Nilai Pengukuran dan Perhitungan}

1. Pengukuran suhu evaporator (SE) dan energi (E)

2. Perhitungan PSE, kW/ton, COP dan EER
Rangkaian Uji

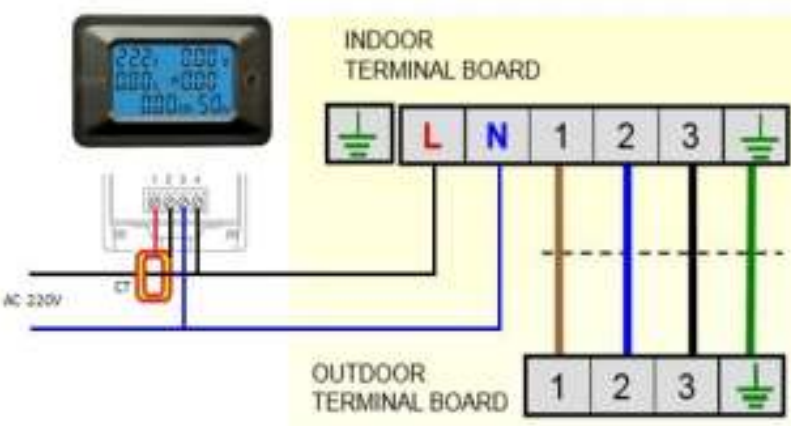

Gambar 2. Rangkaian uji menggunakan $a c$ electric detector model PO6S-100

\section{Rancangan Penelitian}

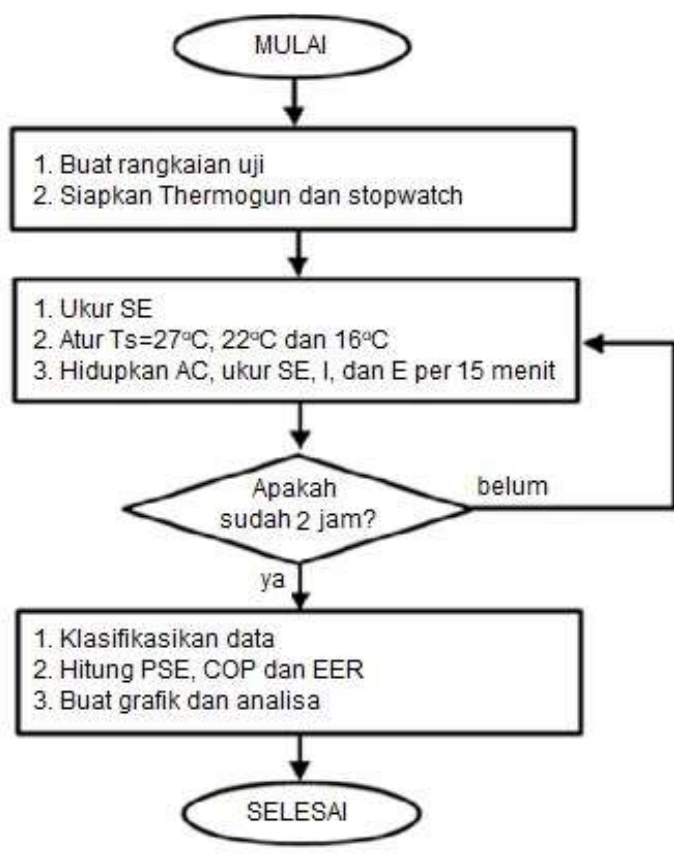

Gambar 3. Flowchart penelitian

\section{HASIL DAN PEMBAHASAN}

\section{Hasil Pengukuran}

Pengukuran pertama pengukuran dengan $\mathrm{TS}=27^{\circ} \mathrm{C}$ yang ke 1 hasil dimasukan ke dalam tabel 2 . 


\section{EEICT}

https://ojs.uniska-bim.ac.id/index.php/eeict

Tabel 2. Hasil Pengukuran dengan $\mathrm{TS}=27^{\circ} \mathrm{C}$ yang ke 1

\begin{tabular}{ccccccc}
\hline & \multicolumn{7}{c}{$\mathrm{TS}=27^{\circ} \mathrm{C}$} \\
$\begin{array}{c}\text { Menit } \\
\text { ke }\end{array}$ & $\mathrm{SE}$ & $\mathrm{V}$ & $\mathrm{I}$ & $\mathrm{PF}$ & $\mathrm{P}$ & $\mathrm{E}$ \\
\hline 0 & 30,2 & & & & & \\
\hline 15 & 20,2 & 229 & 5,47 & 0,8 & 1010,0 & 0,22 \\
\hline 30 & 17,1 & 227 & 4,64 & 0,8 & 851,5 & 0,53 \\
\hline 45 & 17,3 & 228 & 4,21 & 0,8 & 774,6 & 0,66 \\
\hline 60 & 21,7 & 229 & 1,32 & 0,78 & 237,5 & 0,77 \\
\hline 75 & 22,9 & 229 & 1,33 & 0,78 & 240,5 & 0,83 \\
\hline 90 & 23,5 & 232 & 1,27 & 0,79 & 236,9 & 0,90 \\
\hline 105 & 21,8 & 233 & 2,27 & 0,78 & 419.3 & 0,99 \\
\hline 120 & 22,1 & 233 & 1,67 & 0,78 & 304,5 & 1,05 \\
\hline
\end{tabular}

Tabel 3. Hasil Pengukuran dengan $\mathrm{T}_{\mathrm{S}}=27^{\circ} \mathrm{C}$ yang ke 2

\begin{tabular}{ccccccc}
\hline $\begin{array}{c}\text { Menit } \\
\text { ke }\end{array}$ & SE & V & I & PF & P & E \\
\hline 0 & 17,9 & & & & & \\
\hline 15 & 26,3 & 234 & 0,13 & 0,73 & 23,01 & 0,02 \\
\hline 30 & 23,9 & 234 & 0,13 & 0,73 & 22,91 & 0,04 \\
\hline 45 & 24,3 & 234 & 2,49 & 0,77 & 448,50 & 0,05 \\
\hline 60 & 25,6 & 236 & 0,13 & 0,73 & 23,30 & 0,09 \\
\hline 75 & 22,6 & 235 & 1,12 & 0,79 & 212,30 & 0,14 \\
\hline 90 & 26,0 & 236 & 0,13 & 0,73 & 23,53 & 0,16 \\
\hline 105 & 24,6 & 236 & 0,13 & 0,73 & 22,11 & 0,20 \\
\hline 120 & 25,1 & 236 & 0,14 & 0,73 & 24,12 & 0,25 \\
\hline
\end{tabular}

Tabel 4. Hasil Pengukuran dengan $\mathrm{T}_{\mathrm{S}}=22^{\circ} \mathrm{C}$ yang ke 1

\begin{tabular}{|c|c|c|c|c|c|c|}
\hline \multirow{2}{*}{$\begin{array}{l}\text { Menit } \\
\text { ke }\end{array}$} & \multicolumn{6}{|c|}{$\mathrm{Ts}=22^{\circ} \mathrm{C}$} \\
\hline & SE & V & I & PF & $\mathrm{P}$ & $\mathrm{E}$ \\
\hline 0 & 29,7 & & & & & \\
\hline 15 & 20,8 & 229 & 5,35 & 0,80 & 994,20 & 0,22 \\
\hline 30 & 21,3 & 229 & 5,44 & 0,80 & 1010,00 & 0,47 \\
\hline 45 & 21,7 & 230 & 5,47 & 0,80 & 1020,00 & 0,72 \\
\hline 60 & 21,2 & 228 & 5,67 & 0,80 & 1040,00 & 0,98 \\
\hline 75 & 17,6 & 225 & 5,66 & 0,80 & 1030,00 & 1,25 \\
\hline 90 & 17,9 & 226 & 5,61 & 0,80 & 998,00 & 1,51 \\
\hline 105 & 16,9 & 227 & 5,45 & 0,80 & 791,70 & 1,75 \\
\hline 120 & 16,4 & 228 & 1,99 & 0,80 & 771,20 & 1,99 \\
\hline
\end{tabular}

e - ISSN: 2615 - 2169

p - ISSN: $2654-4296$

Tabel 5. Hasil Pengukuran dengan $\mathrm{T}_{\mathrm{S}}=22^{\circ} \mathrm{C}$ yang ke 2

\begin{tabular}{|c|c|c|c|c|c|c|}
\hline \multirow{2}{*}{$\begin{array}{c}\text { Menit } \\
\text { ke }\end{array}$} & \multicolumn{6}{|c|}{$\mathrm{Ts}=22^{\circ} \mathrm{C}$} \\
\hline & SE & $\mathrm{V}$ & I & $\mathrm{PF}$ & $\mathrm{P}$ & E \\
\hline 0 & 30,3 & & & & & \\
\hline 15 & 19,9 & 225 & 5,87 & 0,80 & 1060,00 & 0,25 \\
\hline 30 & 17,6 & 226 & 5,75 & 0,80 & 1050,00 & 0,51 \\
\hline 45 & 16,6 & 227 & 5,64 & 0,80 & 1040,00 & 0,75 \\
\hline 60 & 15,1 & 227 & 5,64 & 0,80 & 1020,00 & 1,02 \\
\hline 75 & 14,3 & 228 & 5,43 & 0,80 & 1000,00 & 1,27 \\
\hline 90 & 14,8 & 227 & 5,41 & 0,80 & 992,60 & 1,52 \\
\hline 105 & 15,7 & 227 & 5,39 & 0,80 & 987,10 & 1,76 \\
\hline 120 & 14,3 & 228 & 5,29 & 0,80 & 976,20 & 2,01 \\
\hline
\end{tabular}

Tabel 6. Hasil Pengukuran dengan $\mathrm{T}_{S}=16^{\circ} \mathrm{C}$ yang ke 1

\begin{tabular}{rrrrrrr}
\hline \multirow{2}{*}{$\begin{array}{l}\text { Menit } \\
\text { ke }\end{array}$} & \multicolumn{7}{c}{$\mathrm{Ts}=16^{\circ} \mathrm{C}$} \\
\cline { 2 - 7 } & SE & V & I & PF & P & E \\
\hline 0 & 30,7 & & & & & \\
\hline 15 & 17,9 & 227 & 4,47 & 0,79 & 807,7 & 0,20 \\
\hline 30 & 16,2 & 227 & 4,39 & 0,79 & 793,9 & 0,40 \\
\hline 45 & 16,3 & 227 & 4,35 & 0,79 & 788,8 & 0,60 \\
\hline 60 & 13,8 & 228 & 4,34 & 0,79 & 786,6 & 0,85 \\
\hline 75 & 15,2 & 227 & 4,30 & 0,79 & 783,3 & 0,99 \\
\hline 90 & 16,5 & 229 & 4,28 & 0,79 & 776,8 & 1,18 \\
\hline 105 & 16,5 & 228 & 4,28 & 0,79 & 776,1 & 1,38 \\
\hline 120 & 16,6 & 229 & 4,24 & 0,79 & 773,1 & 1,57 \\
\hline
\end{tabular}

Tabel 7. Hasil Pengukuran dengan $\mathrm{T}_{\mathrm{S}}=16^{\circ} \mathrm{C}$ yang ke 2

\begin{tabular}{ccccccc}
\hline $\begin{array}{c}\text { Menit } \\
\text { ke }\end{array}$ & \multicolumn{7}{c}{$\mathrm{Ts}=16^{\circ} \mathrm{C}$} \\
\hline 0 & 28,2 & $\mathrm{~V}$ & $\mathrm{I}$ & $\mathrm{PF}$ & $\mathrm{P}$ & $\mathrm{E}$ \\
\hline 15 & 17,0 & 230 & 4,10 & 0,79 & 751,9 & 0,17 \\
\hline 30 & 14,7 & 227 & 4,15 & 0,79 & 753,1 & 0,37 \\
\hline 45 & 14,4 & 225 & 4,12 & 0,79 & 744,3 & 0,55 \\
\hline 60 & 13,4 & 225 & 4,11 & 0,80 & 740,3 & 0,73 \\
\hline 75 & 14,8 & 228 & 4,04 & 0,80 & 740,9 & 0,93 \\
\hline 90 & 14,3 & 226 & 4,08 & 0,80 & 743,1 & 1,10 \\
\hline 105 & 14,2 & 225 & 4,07 & 0,80 & 736.2 & 1,31 \\
\hline 120 & 14,4 & 226 & 4,05 & 0,80 & 739,9 & 1,50 \\
\hline
\end{tabular}

\section{Hasil Perhitungan}

Berikut ini perhitungan data dari tabel 1.2 dilakukan secara manual, selanjutnya akan dilakukan menggunakan Ms Excel. 
1. Perhitungan PSE

$P S E=S E_{\text {Awal }}-S E_{\text {Akhir }}$

$=30,2-22,1$

$=8,1$

2. Perhitungan $\mathrm{kW} /$ ton

$$
\begin{aligned}
\frac{K W}{\text { Ton }} & =\frac{\text { Daya Input }(K W)}{\text { Ton }} \\
& =\left(\frac{\frac{1,05}{\frac{120}{60}}}{\frac{9500}{12000}}\right)=\frac{0,525}{0,791}=0,663
\end{aligned}
$$

3. Perhitungan COP (Coefficient of

Performance)

$$
\begin{aligned}
\text { COP } & =\frac{3,516}{\frac{K W}{\text { Ton }}} \\
& =\frac{3,516}{0,663}=5,30
\end{aligned}
$$

4. Menghitung EER (Efficiency Energy

Ratio)

$$
\begin{aligned}
\text { EER } & =\frac{12}{\frac{K W}{\text { Ton }}} \\
& =\frac{12}{0,663}=18,10
\end{aligned}
$$

\begin{tabular}{|c|c|c|c|c|c|c|c|}
\hline \multirow{3}{*}{ No } & \multicolumn{4}{|c|}{ Pengukuran } & \multicolumn{3}{|c|}{ Perhitungan } \\
\hline & \multicolumn{2}{|c|}{$\mathrm{SE}\left({ }^{\circ} \mathrm{C}\right)$} & \multirow{2}{*}{$\begin{array}{c}\mathrm{E} \\
(\mathrm{kWh})\end{array}$} & \multirow[b]{2}{*}{ PSE } & \multirow{2}{*}{$\mathrm{kW} /$ ton } & \multirow{2}{*}{$\mathrm{COP}$} & \multirow[b]{2}{*}{ EER } \\
\hline & Awal & Akhir & & & & & \\
\hline 1. & 30,2 & 22,1 & 1,05 & 8,1 & 0,663 & 5,30 & 18,10 \\
\hline 2. & 17,9 & 25,1 & 0,25 & $-7,2$ & 0,158 & $\begin{array}{c}22,2 \\
7\end{array}$ & 76,00 \\
\hline 3. & 29,7 & 16,4 & 1,99 & 13,3 & 1,257 & 2,80 & 9,55 \\
\hline 4. & 30,3 & 14,3 & 2,01 & 16,0 & 1,269 & 2,77 & 9,45 \\
\hline 5. & 30,7 & 16,6 & 1,57 & 14,1 & 0,992 & 3,55 & 12,10 \\
\hline 6. & 28,2 & 14,4 & 1,50 & 13,8 & 0,947 & 3,71 & 12,67 \\
\hline
\end{tabular}

Untuk perhitungan selanjutnya penulis menggunakan program Ms Excel dan langsung memasukkan hasilnya ke dalam tabel 1.8

Tabel 8. Hasil Perhitungan PSE, COP dan EER

\section{ANALISA DAN PEMBAHASAN}

Berikut ini penulis akan membuat analisa dan pembahasan berupa perbandingan antara hasil pengukuran $\mathrm{TS}=27^{\circ} \mathrm{C}$ yang ke 1 dan ke 2 .

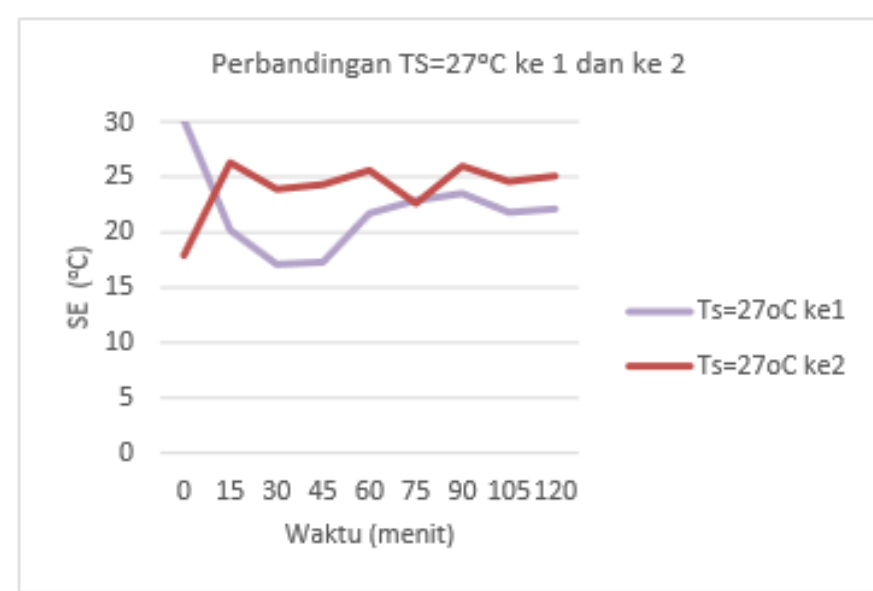

Grafik 1. Perbandingan hasil pengukuran $\mathrm{TS}=27^{\circ} \mathrm{C}$ antara ke 1 dan ke 2

Dari grafik 1 dapat dilihat kedua memiliki nilai SE awal yang berbeda. Pada pengukuran yang ke $1 \mathrm{SE}$ awal $=30,2^{\circ} \mathrm{C}$ lebih tinggi dari $\mathrm{TS}=27^{\circ} \mathrm{C}$. Sedangkan pengukuran yang ke 2 SE awal $=17,9^{\circ} \mathrm{C}$ lebih rendah dari $\mathrm{TS}=27^{\circ} \mathrm{C}$. Sehingga grafik dari pengukuran ke 1 , SE turun sampai $17,1^{\circ} \mathrm{C}$ di menit 30 setelah TS sudah terlewati baru kemudian naik perlahan. Sedangkan pengukuran ke 2 terbalik, SE justru naik sampai $26,30^{\circ} \mathrm{C}$ di menit ke 15 baru kompresor bekerja lagi untuk mendinginkan SE.

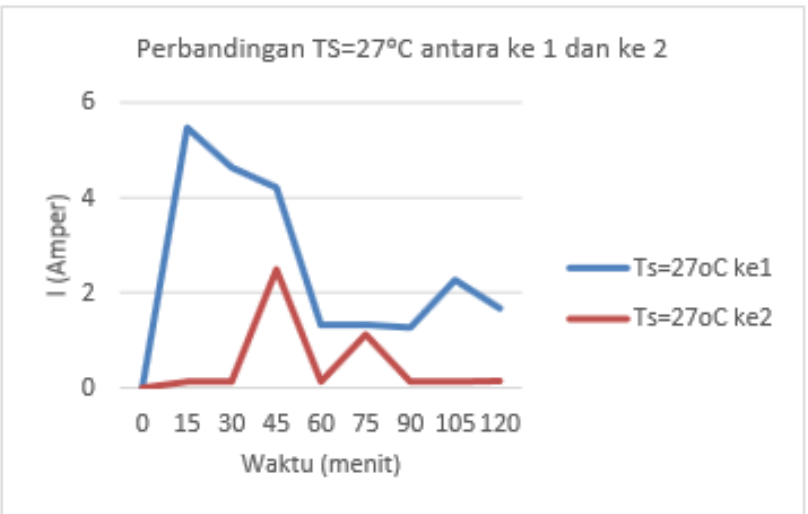

Grafik 2 Perbandingan hasil pengukuran $\mathrm{TS}=27^{\circ} \mathrm{C}$ antara ke 1 dan ke 2

Dari grafik 2 terlihat arus kerja kompresor akibat efek dari SE awal sebelumnya, di menit ke 15 pada pengukuran ke 1 ( $\mathrm{I}=5,47 \mathrm{~A})$, sedangkan pengukuran ke $2(\mathrm{I}=0,13 \mathrm{~A})$. 
EEICT

https://ojs.uniska-bjm.ac.id/index.php/eeict

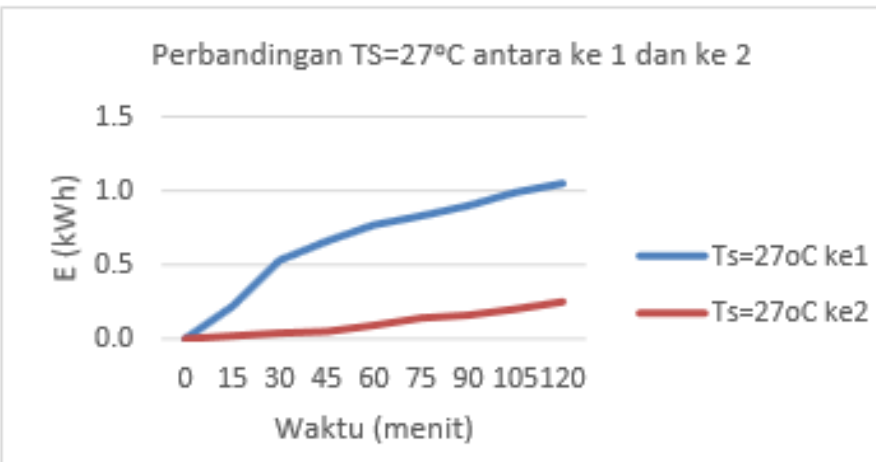

Grafik 3 Perbandingan hasil pengukuran

$\mathrm{TS}=27^{\circ} \mathrm{C}$ antara ke 1 dan ke 2

Dari grafik 3 terlihat grafik pemakaian energi antara pengukuran ke 1 dan ke 2 mempunyai kesamaan pola. Hanya saja nilai dari E tersebut berbeda akibat dari SE awal yang berbeda. Hasil analisa dan pembahasan dari pengukuran $\mathrm{TS}=27^{\circ} \mathrm{C}$ dapat mewakili analisa dan pembahasannya untuk $\mathrm{TS}=22^{\circ} \mathrm{C}$ dan $\mathrm{TS}=27^{\circ} \mathrm{C}$.

Hubungan antara energi $(\mathrm{kWh})$ dengan cooling load (kW/ton) secara. Nilai KW/ton didapatkan dari hasil perhitungan seperti tabel 1.4 .

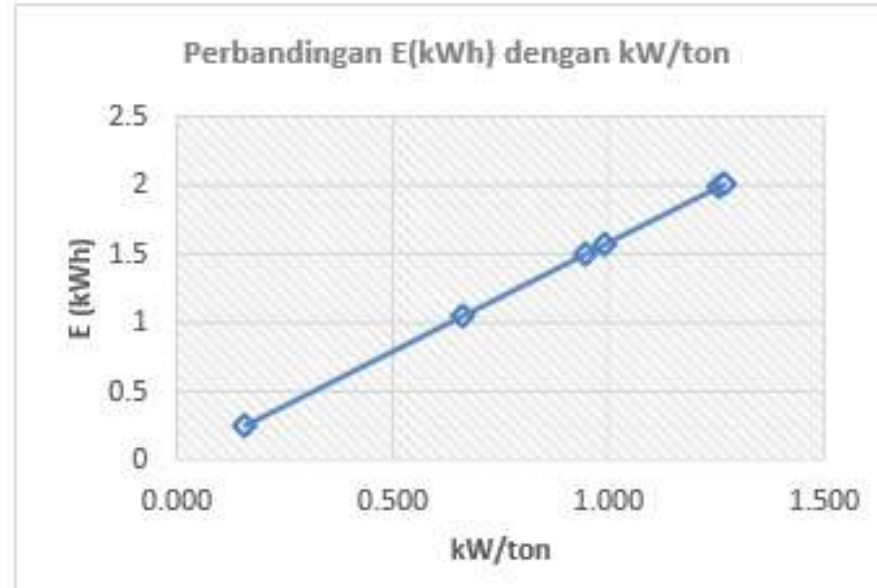

Grafik 4 Perbandingan E (kWh) dengan cooling load ( $\mathrm{kW} /$ ton $)$

Dari grafik 4 terlihat bahwa nilai $\mathrm{E}(\mathrm{kWh})$ berbanding lurus dengan cooling load (kW/ton). e - ISSN: $2615-2169$

p - ISSN: 2654 - 4296

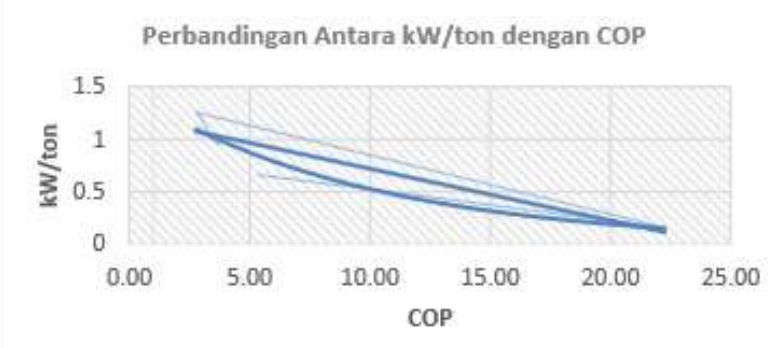

Grafik 5 Perbandingan cooling load (kW/Ton) dengan $\mathrm{COP}$

Dari grafik 5 terlihat bahwa nilai cooling load (kW/ton) berbanding terbalik sesuai dengan COP. Semakin besar nilai cooling load (kW/ton) maka nilai COP akan semakin kecil. Semakin kecil nilai cooling load ( $\mathrm{kW} / \mathrm{ton})$ maka nilai COP semakin besar.

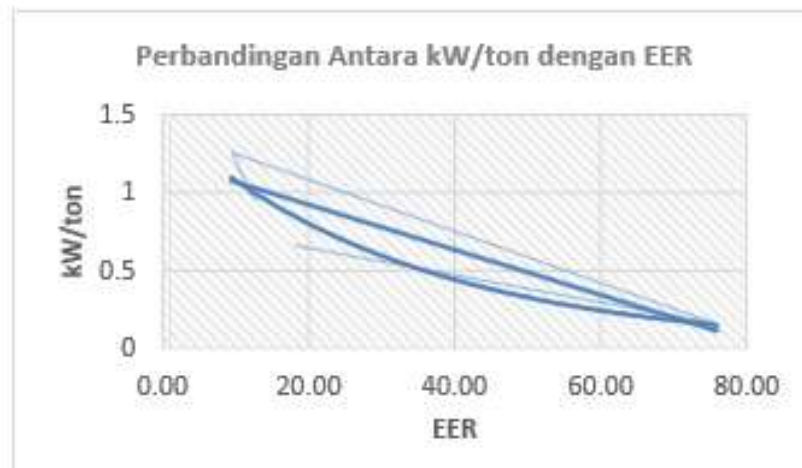

Grafik 6 Perbandingan cooling load (kW/ton) dengan EER

Dari grafik 6 terlihat bahwa nilai cooling load (kW/ton) berbanding terbalik sesuai dengan COP dan EER. Semakin besar nilai cooling load (kW/ton) maka nilai EER akan semakin kecil. Semakin kecil nilai cooling load (kW/ton) maka nilai EER akan semakin besar.

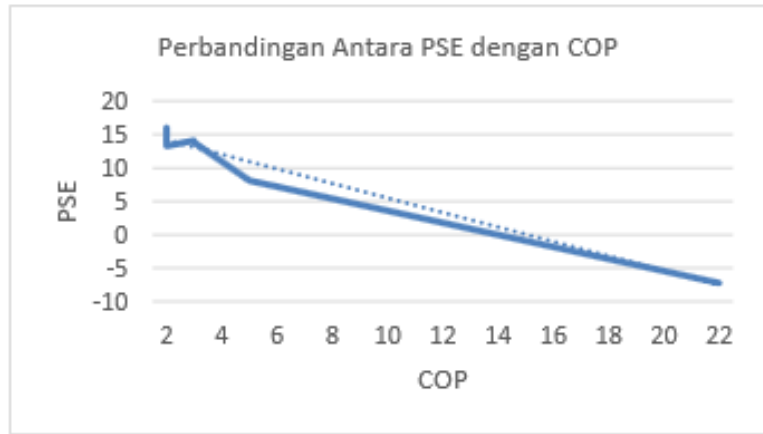




\section{EEICT}

https://ojs.uniska-bjm.ac.id/index.php/eeict

Grafik 7 Perbandingan antara PSE, COP dan EER

Dari grafik 7 terlihat bahwa nilai PSE berbanding terbalik dengan nilai COP. Dari grafik terlihat saat nilai terkecil $\mathrm{PSE}=-7,2$ maka COP mendapatkan nilai terbesar, yaitu $\mathrm{COP}=22,27$. Pada saat posisi nilai terbesar $\mathrm{PSE}=16,01$ maka nilai $\mathrm{COP}$ adalah yang terkecil yaitu $\mathrm{COP}=2,77$.

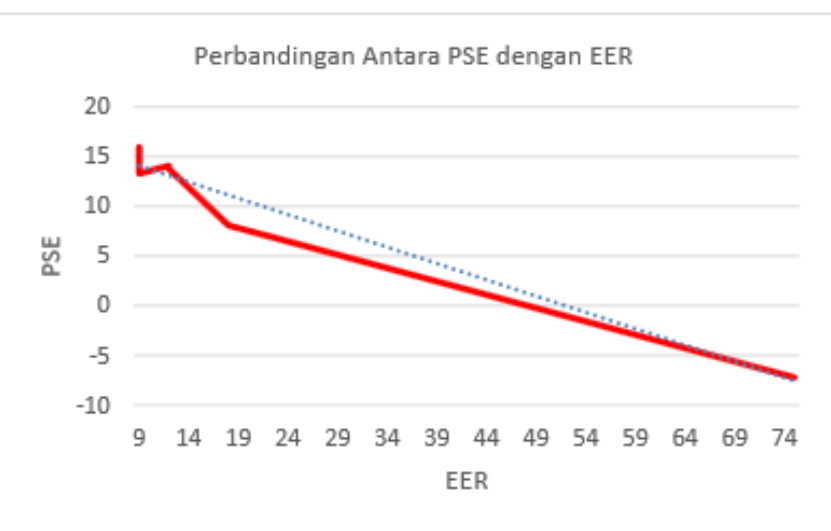

Grafik 8 Perbandingan PSE dengan EER

Dari grafik 8 terlihat bahwa nilai PSE berbanding terbalik dengan nilai EER. Dari grafik terlihat saat nilai terkecil $\mathrm{PSE}=-7,2$ maka EER mendapatkan nilai terbesar, yaitu $E E R=76$. Dan saat nilai terbesar $\mathrm{PSE}=16,01$ maka nilai EER adalah yang terkecil yaitu $E E R=9,45$.

\section{KESIMPULAN}

Dari hasil dan pembahasan pada bab sebelumnya, yang dapat disimpulkan adalah sebagai berikut :

1. Dari hasil dan pembahasan didapatkan identifikasi perubahan suhu evaporator atau PSE dalam 6 kali pengukuran mendapatkan nilai terkecil $\mathrm{PSE}=-7,2$ dan nilai terbesar $\mathrm{PSE}=16,0$. Sedangkan hasil identifikasi kinerja kompresor didapatkan nilai terkecil $\mathrm{COP}=2,77$ dan $\mathrm{EER}=9,45$ dan nilai terbesar $\mathrm{COP}=22,27$ dan $\mathrm{EER}=76,00$.

2. Dari hasil dan pembahasan dapat dianalisa bahwa : semakin kecil perubahan suhu evaporator $(\mathrm{PSE}=-7,2)$ maka kinerja kompresor AC inverter semakin baik e - ISSN: $2615-2169$

p - ISSN: $2654-4296$

$(\mathrm{COP}=22,27$ dan $\mathrm{EER}=76,00)$. Dan semakin besar perubahan suhu evaporator $(\mathrm{PSE}=16,0)$ maka pengaruhnya terhadap kinerja kompresor adalah semakin buruk $(\mathrm{COP}=2,77$ dan EER=9,45).

\section{DAFTAR PUSTAKA}

Anonim. 2017. Peraturan Menteri Energi dan Sumber Daya Mineral Republik Indonesia. Nomor 57 Tahun 2017. Lampiran II.

BEE (Bureau of Energy Efficiency) India. 2002. Energy Performance Assesment of HVAC Systems. India. Ministry of Power. R.K.Puram, New Delhi-110066. 4Ch9. Halaman 115-121.

Eugene Stamper, Richard L Koral (Editors). Handbook of Air Conditioning Heating and Ventilating (Third Edition). Industrial Press Inc., 200 Madison Ave. New York 10016. ISBN 0-8311-1124-0. Hal.30.

Soedjana Sapiie. 2005. Pengukuran dan AlatAlat Ukur Listrik. Pradnya Paramitha:Jakarta.

Supratman Hara, dkk. 1996. Refrigerasi dan Pengkondisian Udara Edisi Kedua. Erlangga:Jakarta.

Esparuling, Budiman Sudia, La Hasanuddin. 2018. Studi Eksperimen Pengaruh Kecepatan Putar Mesin Penggerak Kompresor Pada Sistem Kelistrikan Ac Mobil. Enthalpy-

Jurnal Ilmiah Mahasiswa Teknik Mesin. Vol. 3, No. 1, Maret 2018 e-ISSN: 25028944.Jian Zhao/Yangwei Yu. Brushless DC Motor Fundamentals. AN047 Rev. 1.0.

05/7/2014

https://www.monolithicpower.com/pub/media/do cument/Brushless_DC_Motor_Fund $\underline{\text { amentals.pdf }}$

José Carlos Gamazo-Real*, Ernesto VázquezSánchez and Jaime Gómez-Gil. Position and 
EEICT

https://ojs.uniska-bjm.ac.id/index.php/eeict

Speed Control of Brushless DC Motors Using

Sensorless Techniques and Application Trends. $\quad$ Sensors 2010, 10, 6901-6947; doi:10.3390/s100706901. ISSN 1424-8220

www.mdpi.com/journal/sensors

Joto, Ruwah. 2017.Studi Perbandingan Pemakaian Energi Air Conditioner Inverter Dengan Air Conditioner Konvensional. Jurnal Eltek, [S.1.], V.11, N.1, P.111-121, Oct. 2017.

ISSN 1693-4024.

http://eltek.polinema.ac.id/index.php/eltek/article /view/9

Libor Prokop,Leos Chalupa. 3-Phase BLDC Motor Control with Sensorless Back EMF Zero

Crossing Detection Using 56F80x. AN1914 Rev. $1,11 / 2005$

http://cache.freescale.com/files/product/doc/ $\underline{\text { AN1914.pdf }}$

M. Husni Kotta. 2008. Suhu Netral dan Rentang Suhu Nyaman Manusia Indonesia. Metropilar Volume 6 Nomor 1 Januari 2008. ISSN 1693-6205 http://ojs.uho.ac.id>metropilar>article>view

Sudirman, I Nyoman Suprapta Winaya. 2010. Pengaruh Variasi Putaran Poros Kompresor Terhadap Performansi Sistem Refrigrasi. Prosiding Konferensi Nasionala Engineering Perhotelan (KNEP) 2010.

Tri Harso Karyono. 2001. Penelitian Kenyamanan Termis Di Jakarta SebagaiAcuan Suhu Nyaman Manusia Indonesia. Dimensi Teknik Arsitektur. Vol. 29, No.1, Juli 2001:

24-33

http://dimensi.petra.ac.id/index.php/ars/article/do wnload/15742/15734

Manual Book. 2008. Air Conditioner Inverter. PT. Panasonic Gobel Indonesia. e - ISSN: $2615-2169$

p - ISSN: $2654-4296$

Manual Book. 2009. NewAir Conditioner. PT. Panasonic Gobel Indonesia.

Manual Book. 2017. AC Inverter Instalation Training. PT. Panasonic Gobel Indonesia.

Manual Book. 2017. Air ConditionerSmart Inverter. LG Electronics.

Technical dan Service Manual. 2009. DC Inverter Split Air Conditioner. Sanyo, 2006. 